\title{
Kadarusman Kadarusman $^{\mathrm{a}^{*}}$ and Bunyamin Bunyamin ${ }^{\mathrm{b}}$
}

${ }^{a}$ Accounting Departement, STIE Malangkucecwara, Malang, Indonesia ${ }^{b}$ Management Departement, STIE Malangkucecwara, Malang, Indonesia

C H R O N I C L E

\section{Article history:}

Received: November 18, 2020

Received in revised format:

November 282020

Accepted: December 27, 2020

Available online:

December 28, 2020

Keywords:

Servant Leadership

Trust

Knowledge Sharing

Job Performance

\section{A B S T R A C T}

This study analyzes the effect of servant leadership on job performance with, trust and knowledge sharing as mediating variables. The research is classified in the quantitative analysis used to test the significance between latent variables. The study sample includes 164 of the STIE Malangkucecwara postgraduate program alumni from 2010 to 2019. Data are collected through an online questionnaire and the SmartPls processes the results. The results show that job performance was directly affected by servant leadership. Trust and knowledge sharing are proven as variables that mediate the influence between servant leadership and job performance with the nature of full mediation. Serving leadership tends to increase employee trust in leaders and organizations and stimulates a culture of sharing knowledge to increase employee job performance. The results can be a basis for further studies in the field of management, especially those related to servant leadership, and as material for practical understanding for leaders in various areas of the organization.

C 2021 by the authors; licensee Growing Science, Canada

\section{Introduction}

The leader is one of the main in running and moving private and government organizations' wheels to succeed. Each leader may have different characteristics and leadership styles, so each character and leadership style may increase or decrease employee performance with varying levels of strength. Leaders' characteristics and leadership styles are faced with different attitudes and needs of subordinates, making leadership a complicated relationship between leaders and assistants. Leaders and subordinates have different actions and reactions in organizations with different organizational cultures, and it shows that there are still gaps in management theory related to leadership. Organizational culture can lead to different actions and responses from both the leadership and subordinate sides (Sial, Zulfiqar, Kousar, \& Habib, 2014). The servant leadership style is a leadership style that can improve employee and organizational performance (Al-Amin, 2017; Al-Asadi, Muhammed, Abidi, \& Dzenopoljac, 2019; Barbuto \& Wheeler, 2006). Servant leadership is a leadership model that always involves others in decision making, emphasizing ethical behavior and caring to improve employee development so that it is expected to improve organizational quality (Goh \& Low, 2014). Bass (2000) argues that servant leadership focuses on learning, autonomy, and subordinate growth. The servant leadership style is a leadership style with a unique perspective by providing services to others (Greenleaf, 1977). Servant leadership expected to increase others' ability to continue developing, serving, and meeting others' needs is the primary motivation so that leaders can get the trust of followers (Gregory Stone, Russell, \& Patterson, 2004). Employees in leadership who serve expected to increase their motivation to work are more confident in giving input to the leadership or giving advice and helping Colleagues complete work and have a passion at work.

Servant leadership is expected to be an effective leadership style in creating the passion of subordinates so that workers can collaborate with fellow workers always to share to generate knowledge of practices, encourage the desire to continue to share knowledge. Servant leadership emphasizes paying attention and involving employees in decision-making to gain practical and managerial knowledge. Employees who get attention and are involved are expected to have a passion for contributing to the organization as a service response that they get from the organization, to improve employee performance individually

* Corresponding author.

E-mail address: kadarusman@stie-mce.ac.id (K. Kadarusman) 
(Kuruppuge \& Gregar, 2017). High-performance employees tend to have excellent performance and strive continuously to achieve individual goals by utilizing, learning, and sharing knowledge (Zimmermann \& Ravishankar, 2014). Employees who are involved and get attention tend to get more knowledge than others, so hopefully, the employee desires to do knowledge sharing embedded in him to other members. The performance of individuals and organizations, in general, can be influenced by the willingness of each individual for knowledge sharing. Knowledge sharing among team members is also a valid indicator of team performance. Collaboration between employees through knowledge sharing makes individual performance better (Sial et al., 2014). Focusing on others is a central feature of servant leadership. Organizational members who feel served by the leader tend trust in the leader and the organization (Chinomona, Mashiloane, \& Pooe, 2013). Trust in leaders and organizations can increase employee passion, which can further improve employee performance. Schoorman, Mayer, \& Davis, (2007) stated that trust is a function of leadership; leaders create trust and maintain leadership style or behavior. Trust can grow if employees feel that their leaders are honest and always attach great importance to organizations and employees. The increased trust will increase satisfaction, and vice versa, lack of trust will lead to employee dissatisfaction, ultimately decreasing employees and the organization's performance (Rezaei, Salehi, Shafiei, \& Sabet, 2012). Employees who have trust in top management and managers tend to have high commitment to the organization, making employees work harder and spend more time and energy on their work (Brown \& Leigh, 1996). Trust in organizations facilitates their members' positive psychological condition about the meaningfulness of their work and the sense of security that is a predictor of individual performance (LI \& Tan, 2012). Whereas (Gould-Williams, 2003) states that the belief system is a self-reported performance predictor (effort).

According to Mayer et al. (2008), the results show no direct effect between servant leadership and job satisfaction. The influence of servant leadership with job satisfaction is mediated by organization justice and needs satisfaction. Likewise, the research of Barbuto and Wheeler, (2006) found evidence that servant leadership has a positive influence on employee satisfaction, extra effort harder than members of the organization, and organizational effectiveness. Leaders who provide growth opportunities to give subordinates opportunities to develop can produce positive organization and individual performance (Barbuto \& Wheeler, 2006). Servant leadership with five measurement scales is positively correlated with motivation to do additional work, employee satisfaction, and perceived organizational effectiveness are measured. Job performance is greatly influenced by job satisfaction, so it can be concluded that other variables mediate the influence of servant leadership on job performance. Sendjaya \& Sarros, (2002) argue that servant leadership sees themselves as servants who are trusted to develop and empower followers to reach their full potential. The ability to appreciate and invite members of the organization and consider getting equal opportunities to all organization members are characteristics of servant leadership (Greenleaf, 1977; Gregory Stone et al., 2004). According to Sial et al., (2014), servant leadership can significantly influence workers' attitudes to conduct knowledge sharing positively, involve organizational members, and encourage organization members to conduct experiments and take risks in doing work. The research results of Nobari, Mohamadkhani, \& Davoudi, (2014) showed no significant influence between transcendental spirituality and organizational citizenship behavior. This research gap inspires an examination of servant leadership on job performance by including trust and knowledge sharing variables as mediating variables. Servant leadership tends to involve and pay more attention to organization members in decision making so that organization members have experience and knowledge, both practical and managerial. Organizational members who have experience and knowledge are expected to have a passion for continuing to be involved in organization activities through knowledge sharing among members of the organization. Knowledge sharing among members of an organization can improve mutual communication the organization's members, help each other so that work can be completed well, quickly, and more efficiently. These conditions can enhance each member of the organization's ability, which is expected to increase organization members' job performance. Servant leadership tends to focus on other parties by involving members of the organization in every activity. The involvement of organization members in each event expected to increase the trust of organization members to increase, resulting in increased job performance.

\section{Theoretical review and hypothesis development}

Increasing demands on creativity, employee involvement, sharing behavior among employees, and increasing demands on ethical behavior in organizations requires an approach in leadership style in organizations. These conditions can enhance each member of the organization's ability, which is expected to increase organization members' job performance (Al-Asadi et al., 2019; Liden et al., 2015). It is expected to increase employee trust in the organization, increasing the sharing culture that can ultimately improve employee performance in doing their jobs. This section discusses theories related to research variables and then formulates hypotheses that underlie further analysis.

\subsection{Servant leadership and Trust}

Leader-Member Exchange (LMX) Theory is a leadership theory closest to the social exchange theory stating that social interaction can lead to new phenomena. The theory of social exchange in general, in the context of individual relationships in organizations, is when employees and managers create positive relationships in the workplace to create mutual understanding, to create a work environment that benefits employees and their leaders. LMX theory is a unique leadership theory among other leadership theories because it focuses on dyadic relationships and various types of relationships between leaders and subordinates. Servant leadership is the leadership style closest to LMX Theory because it tends to develop leaders' and members' relationships in the workplace (Liden, Wayne, Zhao, \& Henderson, 2008). Servant leadership seeks to create an environment that serves others who are expected to improve positive work outcomes. This servant leadership expected that subordinates would have wise, healthy, free, empowering, and self-serving or egalitarian qualities (Melchar \& Bosco, 2010). 
According to Greenleaf, (1977), servant leadership must focus on and prioritize others' needs rather than self-interest. Servant leadership is an authentic and modern theory in organizational leadership (Rezaei et al., 2012), which equalizes organization members' ability with their managers and always puts forward that organizational members have the same competence as their leaders. All members have equal dignity and actively participate in management decision-making. Servant leadership is based on the philosophy of serving that oriented to empowering, increasing trust, cooperation, using the ethics of power, and serving others rather than yourself and other things (Greenleaf, 1977). According to Liden et al., (2008), Servant leadership is a multidimensional construct consisting of 7 dimensions: 1) emotional healing is the concern of leaders with personal problems and their members' welfare. 2) Creating value for the community is how much leaders' involvement in helping the community and encourage members to be actively involved in the community. 3) Conceptual skills are the main competencies of a leader in understanding organizational goals and solving work problems. 4) Empowering is the extent to which the leader gives confidence to its members regarding responsibility leaders' giving auto involvement in decision making. 5) Helping subordinates grow successfully, whether the leader helps subordinates grow their full potential and help subordinates' careers. 6) Prioritizing subordinates, how much a leader prioritizes meeting members' needs over their own needs. 7) Ethical behavior, whether the leader is honest, can be trusted, and serves members who are a leader integrity model. The servant leadership characteristics always go beyond their interests and focus on opportunities to help followers grow and develop, listen, empathize, persuade, receive stewardship, and actively build follower potential (Robbins \& Judge, 2017, p. 440).

Based on the results of research Chinomona et al., (2013), the results show that servant leadership has a positive effect on employee confidence in leadership. Servant leadership also has a positive and significant effect on organizational commitment. Meanwhile, based on the study result Goh \& Low, (2014), trust in leaders is statistically a partial mediator between servant leadership and organizational commitment. Good leadership can have the potential to increase the level of trust of organization members, because members of the organization can be more willing to support organizational activities. Servant leadership has a significant and positive effect on trust in leaders (Zargar, Sousan, \& Farmanesh, 2019). Organization members' perceptions of pervasive organizational support tend for organizational members to believe that organizational social norms are to develop individuals in the organization. Therefore, leaders' ability must positively impact the trust of organization members through increased employee perceptions about increasing organization support (Treadway et al., 2004).

Leaders who can be trusted have three characteristics, namely: integrity (integrity), benevolence (virtue), and ability (ability) (Robbins \& Judge, 2017, p. 441). Integrity means maintaining consistency between what is done and said. Benevolence means that people who believed to have sincere interests from the heart have caring and supportive behavior between leaders and followers. Ability is the leader's technical ability and skill because it is impossible to depend on followers of the leader whose is not trusted even though the leader has good intentions and high principles. Based on the capacity description above, the hypothesis can be drawn as follows:

\section{$\mathrm{H}_{1}$ : Servant leadership has a significant and positive effect on trust.}

\subsection{Servant leadership and knowledge sharing}

According to Nonaka, (1994), knowledge is divided into explicit knowledge and tacit knowledge. Explicit knowledge is easy and can be transmitted through formal relationships and carried out systematically. It can be learned in past documents that already exist in the organization, such as procedures, rules, and regulations that can be accessed easily. Tacit knowledge is the knowledge that exists in the minds of each member of the organization. Tacit knowledge is usually in the form of expertise and safety of organizational members that cannot be transmitted through learning from documents but through intense interaction between members. Knowledge sharing is a technique of accessing and gaining new knowledge, applying and transferring knowledge, so that solutions to existing problems in the organization can be faster, better and more efficient (Amin, Ahmed, \& Soomro, 2019). Knowledge sharing is expected to occur at the level of both individuals and organizations. At the individual level, knowledge sharing is expected to communicate among colleagues and help each other complete work better, faster, and more efficiently. At the organizational level, knowledge sharing is capturing, organizing, using, and transferring experience-based knowledge the organization so that knowledge is available and can be understood by others in the organization concerned. Organizations that can act in a superior way to face and win the competition are organizations that have, use, and disseminate knowledge in various business processes that are not owned and cannot be imitated by competitors (Kadarusman, Surachman, Troena, \& Ratnawati, 2019). Possessing, using, and disseminating knowledge can be done through sharing knowledge by individuals in the organization. Knowledge sharing can occur if, between individuals within the organization, there is mutual trust between them, and there is individual trust with the organization. Trust owned by each individual in the organization is intended to reduce each individual's uniqueness, thereby increasing the desire to share knowledge (Renzl, 2008). Servant leadership gives the possibility of having high empowerment behavior, so it tends to increase high-quality student relationships, increasing higher involvement in challenging tasks(Sial et al., 2014).

Knowledge sharing means the transfer, dissemination, and exchange of valuable knowledge, experience, skills, and information from one individual to another member in an organization, whether formal or informal, and can be done through written correspondence, face-to-face communication, or by using an electronic knowledge system (Bock, Zmud, Kim, \& Lee, 2005). Knowledge sharing allows individual learning to flow throughout the organization, building a common understanding of different thoughts, beliefs, knowledge, and experiences to enhance employees' ability and contribute effectively to the organization as a whole (Yang, 2007). The organization's leader's responsibility in knowledge management is motivating 
members of the organization, providing increased income, increasing work, supporting the organization's members, and improving their work. The ability to appreciate and invite members of the organization and consider equal opportunities to all organization members are servant leadership characteristics (Greenleaf, 1977; Gregory Stone et al., 2004). Servant leadership can significantly influence workers' attitudes to knowledge sharing positively, involve members of the organization, and encourage organizational members to carry out experiments and take risks in doing work (Sial et al., 2014). Servant leadership is unique leadership compared to other approaches because it prioritizes serving followers before serving their own needs, acting as serving leaders in all areas of life - work, home, community, and developing organizational members into serving leaders (Liden et al., 2015). Servant leadership is a type of leadership that is very concerned about the empowerment of members of the organization and encourages them to participate in technical and managerial organizations actively. So, servant leadership can encourage positive feelings to share knowledge (Bock et al., 2005). This encourages organizational members to exchange abilities and experiences possessed by each member of the organization through the participation of all members of the organization. Based on this description, this study proposes a second hypothesis as follows:

$\mathrm{H}_{2}$ : Servant leadership has a significant and positive effect on knowledge sharing.

\subsection{Servant leadership and job performance}

Job performance is the result contributed by the members of the employee in the organization regarding their involvement, where the organization can see as productive or unproductive and good performance is if the members of the organization can meet the expectations of the leadership and have an impact on organizational performance (Jalagat, 2016). Job performance is the result of work to achieve organizational goals as measured by performance evaluation on work-related tasks (Sharma, Borna, \& Stearns, 2009). Job performance is the quality and quantity achieved by individuals or groups after completing a task. Servant leadership relies on one-on-one communication to understand the abilities, needs, desires, goals, and potential of their followers and ultimately bring out the best in those individuals (Chinomona et al., 2013). Job Performance is actions and behavior relevant to organizational goals, which are under the control of employees (Salanova, Agut, \& Peiró, 2005). In this study, Job Performance is measured by five dimensions adopted from the study (Manzoor et al., 2019), which explained in detail the variable's operational definition. Organizations need high-performing employees to achieve their goals and to achieve a competitive advantage. Every organization is always looking for ways for the organization's performance to have good performance with high productivity. The productivity of organizational members is achieved through the involvement of organizational members in activities that are important factors for improving organizational members' performance. The involvement of organizational members is obtained through the efforts of the leadership always to empower its members. Empowering members of the organization is a hallmark of servant leadership, so it can be said that the more leaders provide services to their members, can increase the involvement of organizational members that can improve employee performance. Servant leadership places more emphasis on providing services to members of the organization, taking a holistic approach, always prioritizing a sense of togetherness, and sharing power in decision-making to increase organizational members' participation, which can improve job performance. Servant leadership makes followers retaliate for their support by engaging in behaviors that benefit leaders and fellow members, such as citizenship behavior (Ehrhart, 2004). Organizational citizenship behavior (OCB) is a specific work behavior that leads to individual behavior that is beneficial to the organization and is discretionary and is not directly or explicitly recognized by the formal reward system (Kumar, Bakhshi, \& Rani, 2009). Serving leadership emphasizes improving service to others, a holistic approach to work, promoting a sense of togetherness and sharing power in decision making. Since then, Greenleaf, (1977) article on servant leadership has influenced many prominent writers, thinkers, and leaders, so the third hypothesis is:

\section{$\mathrm{H}_{3}$ : Servant leadership has a significant and positive effect on job performance.}

\subsection{Trust and Job Performance}

Achieving personal and organizational goals is always the interdependence of other parties to work together. Members of organizations with different backgrounds are required to be in close contact with one another. The development of mutual trust enables members of organizations with different backgrounds to work together more effectively (R. C. Mayer, Davis, \& Schoorman, 1995; Schoorman et al., 2007). Trust is a person's trust in others that other people will fulfill their desires (Kheiry \& Alirezapour, 2012). Members of the organization who trust each other that one party believes that the other party can meet their needs tend to increase cooperation within the organization, ultimately improving organizational performance. The organization members will respect their leaders, and the members of the organization will be motivated to be involved in doing their work more than they should (Podsakoff, Mackenzie, Moorman, \& Fetter, 1990). Schoorman et al., (2007) state that increasing labor diversity requires that people with very different backgrounds touch and are closely related. A diverse workforce is less able to rely on interpersonal equality, background, and experience to contribute to mutual efforts and efforts to increase the willingness to work together. Therefore, we need a mechanism to develop mutual trust between members of the organization to enable members of the organization to work together more effectively, which in the end each individual can improve his work. (Singh \& Desa, 2018) who examined the public sector stated that trust in organizations is positively correlated to job performance. Trust is the willingness of one party to be vulnerable to another party's actions based on the expectation that the other party will take certain actions that are important to each party (Mayer et al., 1995). Trust is not just taking risks, but is more a willingness to take risks. Trust measured by a) I feel pretty confident that my leader will always try to treat me fairly, b) my manager will never try to profit by cheating workers, c) I have full faith in the integrity of my 
manager/supervisor, d) I feel a strong loyalty to the leader, e) I will support my leader in almost any emergency, f) I have a strong sense of loyalty towards my leader (Podsakoff et al., 1990). From this description, the fourth hypothesis is:

\section{$\mathrm{H}_{4}$ : Trust has a significant and positive effect on job performance.}

\subsection{Knowledge sharing and job performance}

Knowledge sharing is how new knowledge is accessed and obtained by members of the organization and how members of the organization apply and transfer that knowledge, solve problems and make decisions faster, better, and more efficiently. Knowledge sharing is the task of providing information and knowledge, helping and collaborating with others to solve problems, developing new ideas, and implementing policies or procedures (Wang \& Noe, 2010). Knowledge sharing means offering knowledge that embedded in the minds of individuals to other members in their closeness. Knowledge sharing, generally accepted as a positive motive for individual and organizational performance (Kuruppuge \& Gregar, 2017). Organization members who gain experience from others through knowledge sharing provide ways to avoid inefficiencies in products and processes and business effectiveness. Knowledge sharing is possible in organizations if there is mutual trust in other people and organizations. Through knowledge, sharing is also expected to increase the organization's members' positive sense to share knowledge, improve knowledge and skills, individual performance, and organizational performance. A person's attitude in sharing knowledge in an organization can occur if the organization's leadership provides opportunities and good opportunities for knowledge sharing to occur (Bock et al., 2005). So that it can be said that servant leadership that always puts the development of organizational members can be a good introduction in improving the attitudes of members of the organization to share knowledge so that the ability, skills, and performance of individual members of the organization can improve. The attitude of someone in sharing knowledge, according to Bock et al., (2005), was measured by five items, namely: 1) Sharing my knowledge with other members of the organization is good. 2) Sharing my knowledge with other members of the organization is dangerous. 3) Sharing my knowledge with other organizational members is a pleasant experience. 4) Sharing my knowledge with other members of the organization is very valuable to me. 5) Sharing my knowledge with other organizational members is done in a good manner. Srivastava et al. (2006) result research show that knowledge sharing among team members is a valid indicator of team performance. Close collaboration and coordination among members in an organization through activities such as sharing knowledge directly results in better individual work performance (Kuruppuge \& Gregar, 2017). Organizational members who have benefited from their presence in the organization should properly contribute to the organization as part of the rewards they receive from the organization. So the fifth research hypothesis is as follows:

$\mathrm{H}_{5}$ : Knowledge sharing has a significant and positive effect on job performance.

\subsection{Servant leadership and job performance mediated by trust and knowledge sharing}

According to Chinomona et al. (2013), Servant leadership relies on one-on-one communication to understand the abilities, needs, desires, goals, and potential of each so that it can positively impact each individual's achievements. Servant leadership has a positive effect on employee trust in leadership, and servant leadership also has a positive and significant effect on organizational commitment. Meanwhile, according to Ehrhart, (2004), servant leadership increases organizational citizenship behavior (OCB) members of the organization allowing members of the organization to do work outside the formal requirements. Singh \& Desa, (2018) stated that trust in organizations would increase job performance. Knowledge sharing can generally be accepted as a positive motive to improve individuals' performance and the organization's performance (Kuruppuge \& Gregar, 2017). Meanwhile, according to Barbuto \& Wheeler, (2006) the influence between servant leadership and job satisfaction occurs not directly but is mediated by other variables. This study proposed to add trust and knowledge sharing variables to the impact between servant leadership on job performance so that the following hypotheses are:

$\mathrm{H}_{6}$ : The influence of servant leadership on job performance is mediated by trust and knowledge sharing.

Based on a theoretical study and the relationship between the variables that have been described, the following research model can be proposed:

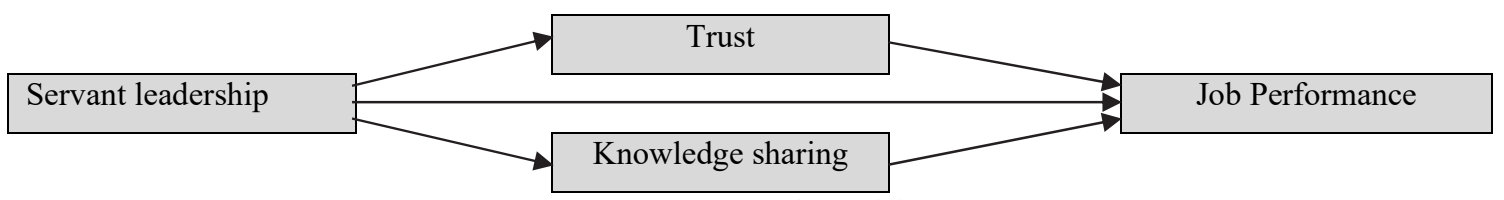

Fig. 1. Research Model

Source: (Chinomona et al., 2013; Kuruppuge \& Gregar, 2017; Liden et al., 2015; Sial et al., 2014)

\section{Research methodology}

\subsection{Population and Samples}

The population in this research are of the STIE Malangkucecwara postgraduate program alumni from 2010 to 2019 . The number of alumni is 316 people. The questionnaire was sent online and returned as many as 164 questionnaires with a response rate of $51.89 \%$. 
The operational definitions of each variable in this study are as follows:

Table 1

Definition of Operational Variables

\begin{tabular}{|c|c|c|}
\hline Variable & Definition & Item/indicator \\
\hline $\begin{array}{l}\text { Servant Leadership } \\
\text { (Liden et al., 2015) }\end{array}$ & $\begin{array}{l}\text { Servant leadership prioritizes } \\
\text { serving followers before serving } \\
\text { their own needs, acting as servant } \\
\text { leaders in all areas of life - work, } \\
\text { home, and community, and de- } \\
\text { veloping followers into servant } \\
\text { leaders. }\end{array}$ & $\begin{array}{l}\text { 1. My leader can find out if something related to work is } \\
\text { wrong. } \\
\text { 2. My leader makes my career development a priority. } \\
\text { 3. I will seek help from my leader if I have a personal prob- } \\
\text { lem. } \\
\text { 4. My leader emphasizes the importance of giving back to the } \\
\text { community. } \\
\text { 5. My leader places my best interests above his own. } \\
\text { 6. My leader gives me the freedom to handle difficult situa- } \\
\text { tions in the way I feel is best. } \\
\text { 7. My leader will NOT compromise ethical principles to } \\
\text { achieve success. }\end{array}$ \\
\hline $\begin{array}{l}\text { Trust (Podsakoff et } \\
\text { al., 1990) }\end{array}$ & ce and & $\begin{array}{l}\text { 1. I feel pretty confident that my leader will always try to } \\
\text { treat me fairly. } \\
\text { 2. My manager will never try to profit by cheating workers. } \\
\text { 3. I have full confidence in the integrity of my manager/su- } \\
\text { pervisor. } \\
\text { 4. I feel a strong loyalty to my leader. } \\
\text { 5. I will support my leader in almost any emergency. } \\
\text { 6. I have a strong sense of loyalty towards my leader. }\end{array}$ \\
\hline $\begin{array}{l}\text { Knowledge Sharing } \\
\text { (Bock et al., 2005) }\end{array}$ & $\begin{array}{l}\text { Knowledge sharing means } \\
\text { the transfer, dissemination and } \\
\text { exchange of valuable knowledge, } \\
\text { experience, skills, and infor- } \\
\text { mation from one individual to an- } \\
\text { other in an organization, whether } \\
\text { formal or informal, and can be } \\
\text { done through written correspond- } \\
\text { ence, face to face, or with an elec- } \\
\text { tronic knowledge system }\end{array}$ & $\begin{array}{l}\text { 1. Sharing my knowledge with other members of the organi- } \\
\text { zation is good. } \\
\text { 2. Sharing my knowledge with other organizational members } \\
\text { is very useful. } \\
\text { 3. Sharing my knowledge with other organizational members } \\
\text { is a pleasant experience. } \\
\text { 4. Sharing my knowledge with other organizational members } \\
\text { is very valuable to me. } \\
\text { 5. Sharing my knowledge with other members of the organi- } \\
\text { zation is a good way. }\end{array}$ \\
\hline $\begin{array}{l}\text { Job Performance } \\
\text { (Manzoor et al., } \\
\text { 2019) }\end{array}$ & $\begin{array}{l}\text { Job Performance is the actions } \\
\text { and behavior relevant to organi- } \\
\text { zational goals, which are under } \\
\text { the control of employees. }\end{array}$ & $\begin{array}{l}\text { 1. I consistently complete the tasks specified in my job de- } \\
\text { scription. } \\
\text { 2. I consistently meet job performance requirements. } \\
\text { 3. I fulfill all the responsibilities required by my work. } \\
\text { 4. I consistently fulfill my obligations to do my job. } \\
\text { 5. I always succeed in doing important tasks. }\end{array}$ \\
\hline
\end{tabular}

\subsection{Method}

The analysis technique used is an analysis using the SmartPLS 2.0 program, which is carried out with the following steps:

\subsubsection{Outer models or measurement models}

Outer models or measurement models are used to measure the validity and reliability of research instruments. Validity Test used to ensure that respondents will understand the items used. Validity analyzed by discriminant validity and convergent validity. Validity is analyzed by discriminant validity and convergent validity. Discriminant validity is said to be valid if AVE (Average variance extracted) $>0.5$, Discriminant validity is also analyzed by cross loading factor (Hair., Black, Babin, \& Anderson, 2009; Joseph F. Hair, Hult, Ringle, \& Sarstedt, 2017). Convergent validity is measured by loading factors and is said to be valid if the loading factor value $>0.7$ (Hair. Et al., 2009). Reliability is a measure that assesses whether the measuring instrument has performed its function properly. Reliability is said to be reliable if the Cronbach alpha value $>0.5$ and composite reliability $>0.7$.

\subsubsection{Inner model test}

This test is used with the R-square test, the Prediction relevance test, and the GoF (goodness of fit) test, and this test used to assess the strength of the proposed model in the study. Prediction relevance value $\left(\mathrm{Q}^{2}\right)$ is calculated by the formula $\left(\mathrm{Q}^{2}\right)=1$ $\left(1-\mathrm{R}^{2}\right)\left(1-\mathrm{R} 2^{2}\right) \ldots\left(1-\mathrm{Rn}^{2}\right)$, small $=0.02$, medium $=0.15$ and large $=0.35($ Joseph F. Hair et al., 2017). GoF (goodness of 
Fit) value is calculated using the formula: $\mathrm{GoF}=\sqrt{ }$ (average AVE $\mathrm{x}$ average $\mathrm{R}^{2}$ ), with the following criteria: $\mathrm{small} \mathrm{GoF}=0.1$ medium $=0.25$ and large $=0.38$ (Tenenhaus, Vinzi, Chatelin, \& Lauro, 2005). The next test is testing each hypothesis proposed in this study.

\section{Result and discussion}

\subsection{Outer model}

This outer model test used to assess the validity and reliability of research instruments, and the results can be seen in Table 2 . The loading factor of all indicators shows a value greater than 0.7 , that all indicators meet the convergent validity requirements. The AVE value of all latent variables $>0.5$. The loading factor of each indicator in the latent construct is greater than the indicator value in assessing other latent constructs. The measurement of AVE and cross-loading factors can conclude that it meets the discriminant validity requirements. The composite reliability values of each construct range between 0.887 0.911, greater than 0.7, while the Cronbach alpha value ranges from $0.842-0.886$, all of which are greater than 0.5 . Composite reliability and Cronbach alpha values greater than required indicate that the measuring instruments in this study have taken accurate and consistent measurements.

Table 2

Validity and reliability

\begin{tabular}{|c|c|c|c|c|c|c|c|}
\hline & \multicolumn{4}{|c|}{ Loading factor and cross loading } & \multirow{2}{*}{ AVE } & \multirow{2}{*}{ Composite Reliability } & \multirow{2}{*}{ Cronbach Alpha } \\
\hline & Job & K. Sharing & Servant & Trust & & & \\
\hline & \multicolumn{4}{|c|}{ Job Performance } & \multirow[t]{6}{*}{0.620} & \multirow[t]{6}{*}{0.891} & \multirow[t]{6}{*}{0.847} \\
\hline OB1 & 0.823 & 0.397 & 0.375 & 0.516 & & & \\
\hline OB2 & 0.789 & 0.210 & 0.289 & 0.450 & & & \\
\hline OB3 & 0.783 & 0.235 & 0.386 & 0.439 & & & \\
\hline OB4 & 0.745 & 0.194 & 0.361 & 0.358 & & & \\
\hline \multirow[t]{2}{*}{ OB5 } & 0.794 & 0.362 & 0.347 & 0.432 & & & \\
\hline & \multicolumn{4}{|c|}{ Knowledge Sharing } & \multirow[t]{6}{*}{0.612} & \multirow[t]{6}{*}{0.887} & \multirow[t]{6}{*}{0.842} \\
\hline KNS1 & 0.201 & 0.779 & 0.360 & 0.336 & & & \\
\hline KNS2 & 0.259 & 0.727 & 0.175 & 0.351 & & & \\
\hline KNS3 & 0.315 & 0.791 & 0.264 & 0.249 & & & \\
\hline KNS4 & 0.344 & 0.798 & 0.335 & 0.406 & & & \\
\hline \multirow[t]{2}{*}{ KNS5 } & 0.292 & 0.813 & 0.271 & 0.395 & & & \\
\hline & \multicolumn{4}{|c|}{ Servant Leadership } & \multirow[t]{8}{*}{0.595} & \multirow[t]{8}{*}{0.911} & \multirow[t]{8}{*}{0.886} \\
\hline SLD1 & 0.414 & 0.145 & 0.759 & 0.456 & & & \\
\hline SLD2 & 0.240 & 0.219 & 0.809 & 0.471 & & & \\
\hline SLD3 & 0.407 & 0.357 & 0.790 & 0.473 & & & \\
\hline SLD4 & 0.293 & 0.306 & 0.715 & 0.527 & & & \\
\hline SLD5 & 0.345 & 0.351 & 0.746 & 0.514 & & & \\
\hline SLD6 & 0.354 & 0.224 & 0.774 & 0.519 & & & \\
\hline \multirow[t]{2}{*}{ SLD7 } & 0.342 & 0.343 & 0.804 & 0.508 & & & \\
\hline & \multicolumn{4}{|c|}{ Trust } & \multirow[t]{7}{*}{0.614} & \multirow[t]{7}{*}{0.905} & \multirow[t]{7}{*}{0.874} \\
\hline TRS1 & 0.484 & 0.337 & 0.488 & 0.767 & & & \\
\hline TRS2 & 0.417 & 0.412 & 0.526 & 0.798 & & & \\
\hline TRS3 & 0.478 & 0.298 & 0.569 & 0.785 & & & \\
\hline TRS4 & 0.493 & 0.277 & 0.451 & $\mathbf{0 . 8 2 7}$ & & & \\
\hline TRS5 & 0.385 & 0.349 & 0.458 & 0.769 & & & \\
\hline TRS6 & 0.374 & 0.427 & 0.526 & 0.752 & & & \\
\hline
\end{tabular}

Source: processed data

\subsection{Inner Model}

\subsubsection{Model Testing}

Model testing used to determine whether the model proposed in this study has a match or suitability between the model and data. The model test results are as follows

Table 3

$\underline{\mathrm{R}^{2}, \mathrm{Q}^{2} \text { dan Gof }}$

\begin{tabular}{lcc} 
& & $\mathrm{R}^{2}$ \\
\hline Job Performance & 0.342 & $\mathrm{Q}^{2}$ \\
Knowledge Sharing & 0.135 & 0.667 \\
Servant leadership & 0.415 & 0.426 \\
$\quad$ Trust & &
\end{tabular}

Predictive relevance $\left(Q^{2}\right)=1-(1-0.342)(1-0.135)(1-0.415)=0.667$ 
Goodness of Fit $(\mathrm{GoF}) \quad=\sqrt{ }(0.610 \times 0.297)=0.426$

$\mathrm{R}^{2}$ value of each variable $>0$ indicates that each independent variable has predictive power for the dependent variable. Predictive relevance value $0.667>0.35$ shows that the observed value generated by the research model and its parameter estimation is large. Based on the predictive criteria, the relevance of the research model is robust. The Goodness of Fit (GoF) value of $0.426>0.38$ indicates that there is a match or a match between certain observations with the frequency obtained based on the expected value. Based on the inner model analysis, this model has fulfilled the requirements to be used in further analysis.

\subsection{Hypothesis Test}

Figure and tables of analysis results with SmartPls 2.0 with bootstrapping are as follows:

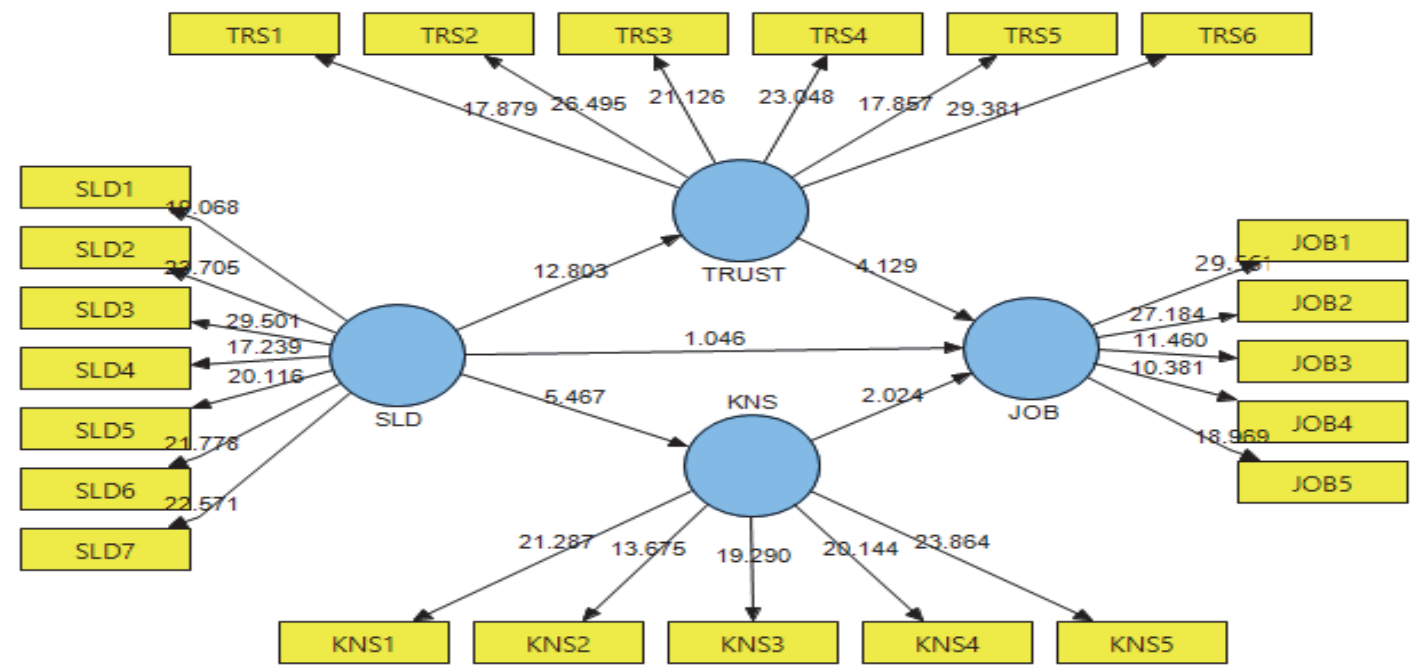

Fig. 2. Full Model

Table 4

Total effects and path coefficients

\begin{tabular}{|c|c|c|c|c|c|c|}
\hline & $\begin{array}{c}\text { Original } \\
\text { Sample }(\mathrm{O})\end{array}$ & $\begin{array}{c}\text { Sample } \\
\text { Mean (M) }\end{array}$ & $\begin{array}{c}\text { Standard } \\
\text { Deviation } \\
\text { (STDEV) }\end{array}$ & $\begin{array}{c}\text { Standard } \\
\text { Error } \\
\text { (STERR) } \\
\end{array}$ & $\begin{array}{l}\text { T Statistics } \\
\text { O/STERR }\end{array}$ & Result \\
\hline \multicolumn{7}{|c|}{ Total effect } \\
\hline $\mathrm{KNS} \rightarrow \mathrm{JOB}$ & 0.130 & 0.136 & 0.064 & 0.064 & 2.024 & Sig. \\
\hline $\mathrm{SLD} \rightarrow \mathrm{JOB}$ & 0.447 & 0.446 & 0.087 & 0.087 & 5.165 & Sig. \\
\hline $\mathrm{SLD} \rightarrow \mathrm{KNS}$ & 0.367 & 0.373 & 0.067 & 0.067 & 5.467 & Sig. \\
\hline SLD $\rightarrow$ TRUST & 0.644 & 0.648 & 0.050 & 0.050 & 12.803 & Sig. \\
\hline TRUST $\rightarrow$ JOB & 0.423 & 0.424 & 0.103 & 0.103 & 4.129 & Sig. \\
\hline \multicolumn{7}{|c|}{ Path coefficient } \\
\hline $\mathrm{KNS} \rightarrow \mathrm{JOB}$ & 0.130 & 0.136 & 0.064 & 0.064 & 2.024 & Sig. \\
\hline SLD $\rightarrow$ JOB & 0.126 & 0.119 & 0.121 & 0.121 & 1.046 & Not. Sig. \\
\hline $\mathrm{SLD} \rightarrow \mathrm{KNS}$ & 0.367 & 0.373 & 0.067 & 0.067 & 5.467 & Sig. \\
\hline $\mathrm{SLD} \rightarrow \mathrm{TRUST}$ & 0.644 & 0.648 & 0.050 & 0.050 & 12.803 & Sig. \\
\hline TRUST $\rightarrow$ JOB & 0.423 & 0.424 & 0.103 & 0.103 & 4.129 & Sig. \\
\hline
\end{tabular}

Source: processed data

KNS = Knowledge sharing, JOB $=$ Job Performance, SLD $=$ Servant Leadership

The first hypothesis that servant leadership has a significant and positive effect on trust. The total effect in Table 4 shows the value of $\beta=0.644$ with a statistical $\mathrm{t} 12,803>1.97(\mathrm{t}$ table $\alpha=5 \%$, df $=160)$, means that the first hypothesis is accepted significantly and positively. Servant leadership always prioritizes ethical behavior, involving members of the organization in decision making, caring and serving in the improvement and development of its members so that it tends to increase subordinates' trust in their leaders. Trust in leaders tends to grow and develop if subordinates have believe that leaders act honestly and always prioritize employees and organizations. This study's results support the study of Chinomona et al., (2013), which states if subordinates who are well served will trust more when leaders and organizations. Reinke, (2004), states that servant leadership is an independent variable that causes or produces a culture or community of trust, which in turn results in organizational success. Thus, the trust serves as an intervening variable between servant leadership (independent variable) and organizational success (dependent variable). Trust is a function of leadership, where leaders create trust and maintain through leadership style or behavior. Leaders are responsible for building an organizational culture based on trust, which will produce organizational success. Leaders must demonstrate the ability to predict consistently in an open and ethical atmosphere to build a culture of trust. This is in line with serving leadership, which is leadership based on values (Greenleaf, 1977), especially the 
values of trust, respect and service. The second hypothesis is that servant leadership has a significant and positive influence on knowledge sharing. The total effect between servant leadership and knowledge sharing is $\beta=0.367$ with $\mathrm{t}$ value $=5.467>$ 1.97 ( $\mathrm{t}$ table $\alpha=5 \%, \mathrm{df}=160$ ), it means that it is received significantly and positively. Servant leadership can significantly improve the behavior of subordinates to share knowledge. Servant leadership tends to empower its members in decisionmaking to increase subordinates' enthusiasm by always collaborating and sharing with others to gain practical experience and encourage sharing knowledge. Decision making by involving subordinates can provide both practical and managerial experience, and subordinates also feel paid attention and involved, so that subordinates become eager to contribute to the organization in response to the services they receive from the organization. Leaders who are always empowering make sharing knowledge among fellow members of the organization more enjoyable. This study supports the findings of Sial et al., (2014) and Bock et al., (2005), where servant leadership influences workers' attitudes to share knowledge, engages subordinates, encourages subordinates to experiment, risk-taking in doing work. Through empowerment can encourage subordinates to participate actively in every organizational activity, thereby encouraging subordinates' positive feelings to share knowledge Bock et al., (2005). This study also supports the findings Amin et al., (2019) explain the benefits of knowledge sharing behavior that can be overcome through leadership models that serve and encourage employee participation.

The third hypothesis is servant leadership has a significant and positive influence on job performance. The coefficient of the total effect in Table 4 for the influence between servant leadership and job performance shows the coefficient $\beta$ of 0.447 with a statistical $\mathrm{t}$ value of $5.165>1.97(\mathrm{t}$ table $\alpha=5 \%, \mathrm{df}=160)$ means significant and positive. Leaders who serve members of the organization can improve the job performance of their members. Servant leadership relies on one-on-one communication to understand the abilities, needs, desires and goals, and subordinates' potential to bring the best impact for members of the organization. The involvement of organizational members is an important factor in increasing productivity, and increasing the involvement of organization members requires leaders who emphasize the development of their members. Leaders who involve their members and always give opportunities to their members are characteristics of serving leadership.

This study is in line with Barbuto \& Wheeler, (2006)'s findings that servant leadership can improve other positive performance for employees, such as the extra effort made by employees and the perception of organizational effectiveness. Leaders must recognize the positive results of their approach in empowering and developing their members to provide job satisfaction, ultimately contributing to the employees involved and improving their performance. Servant leadership reflects the organization's needs at the time of recovery because it helps reunite organizational members. This research is in line with the statement Brewer, (2010) that having sincere servant leadership can create job satisfaction and increase productivity.

The fourth hypothesis is that trust has a positive and significant effect on job performance. Based on the total effect value in table 4, the coefficient $\beta=0.423$ is obtained, with a value of $t=4.129>1.97$ ( $\mathrm{t}$ table $\alpha=5 \%$, $\mathrm{df}=160$ ), because the value of $\mathrm{t}$ is greater than the value of $\mathrm{t}$ table means the fourth hypothesis is accepted. Subordinate trust in the leadership and organization as a whole can improve job performance. The trust of the organization's members in their leaders and organizations tends to do more work than they are supposed to do. Trust plays an important role in the relationship between the organization and its leaders to increase job satisfaction, commitment to the organization and reduce transaction costs, especially supervision costs. Trust in superiors is also highly valued because it can improve employee performance that supports organizational effectiveness and competitiveness. This research supports research (Gould-Williams, 2003; Li \& Tan, 2012). Organization members who feel confident getting fair treatment, honest leadership, and who do not take personal benefits can motivate members to complete their tasks even more than what is needed and are always responsible for their work. These conditions can ultimately reduce the cost of supervision of subordinate superiors, increase job satisfaction, and the performance of each member of the organization that can improve organizational competitiveness.

The fifth hypothesis is that knowledge sharing has a significant and positive effect on job performance. Coefficient $\beta=0.130$ with a value of $\mathrm{t}=2.024>1.97$ ( $\mathrm{t}$ table $\alpha=5 \%, \mathrm{df}=160$ ), because the value of $\mathrm{t}$ statistic is greater than the value of $\mathrm{t}$ table then the fifth hypothesis is significantly accepted. The positive $\beta$ coefficient means increasing knowledge sharing among members of the organization can improve each member of the organization's job performance. Increased mutual information about knowledge (tacit knowledge, explicit knowledge), collaborating, helping each other in solving problems can improve individual abilities, both practical and managerial to improve the performance of members of the organization.

This study supports the research of Kuruppuge and Gregar, (2017), which states that sharing of knowledge both tacit knowledge or explicit knowledge is positively correlated both partially and jointly with organizational performance and individual performance. Organization employees must contribute to their organizations in response to what they get from the organization. Employees who obtain knowledge from the organization and fellow members of the organization, both practical and managerial, can increase the organization's ability to improve job performance, which can support organizational performance and organizational competitive advantage. The sixth hypothesis is the influence of servant leadership on job performance mediated by trust and knowledge sharing. Based on the results of the total effect in table 4 , the direct effect between servant leadership on job performance with a value of $\beta=0.447$ and a calculated $\mathrm{t}$ value of $5.165>1.97(\mathrm{t}$ table $\alpha=5 \%$, $\mathrm{df}=$ 160) means significant. Increased servant leadership behavior tends to improve job performance. The path coefficient used to assess servant leadership's effect on job performance after entering trust and knowledge sharing variables results in $\beta=0.126$ and $\mathrm{t}=1.046(\mathrm{t}$ table $\alpha=5 \%, \mathrm{df}=160)$, meaning that after entering mediation variables, the effect becomes not significant. After entering mediation variables, the insignificant effect is proven that trust and knowledge sharing are mediating variables with full mediation nature. This study supports research D. M. Mayer et al., (2008), those other variables mediate the influence of servant leadership on job performance. 


\section{Conclusion}

The study has concluded that servant leadership had a positive and significant influence on trust, knowledge sharing, and job performance. The application of servant leadership in organizations tends to increase trust, knowledge sharing and job performance. Trust and knowledge sharing affect job performance. Organizations that implement servant leadership in organizations tend to increase trust, knowledge sharing and job performance. Trust and knowledge sharing affect job performance. Increasing trust, and sharing knowledge in organizations can improve job performance. Trust and knowledge sharing become variables that mediate the influence between servant leadership and job performance with absolute mediation.

\section{References}

Al-Amin, M. (2017). Transformational Leadership and Employee Performance Mediating Effect of Employee Engagement. North South Business Review, 7(2), 28-40.

Al-Asadi, R., Muhammed, S., Abidi, O., \& Dzenopoljac, V. (2019). Impact of servant leadership on intrinsic and extrinsic job satisfaction. Leadership and Organization Development Journal, 40(4), 472-484. https://doi.org/10.1108/LODJ-092018-0337

Amin, H., Ahmed, F., \& Soomro, R. H. (2019). Servant Leadership Improves the Knowledge Sharing Behavior of Employees: A Case of Higher Education Sector in Pakistan. Etikonomi, 18(1), 1-12. https://doi.org/10.15408/etk.v18i1.6190

Barbuto, J. E., \& Wheeler, D. W. (2006). Scale development and construct clarification of servant leadership. Group and Organization Management, 31(3), 300-326. https://doi.org/10.1177/1059601106287091

Bass, B. M. (2000). The Future of Leadership in Learning Organizations. Journal of Leadership Studies, 7(3), 18-40. https://doi.org/10.1177/107179190000700302

Bock, G. W., Zmud, R. W., Kim, Y. G., \& Lee, J. N. (2005). Behavioral intention formation in knowledge sharing: Examining the roles of extrinsic motivators, social-psychological forces, and organizational climate. MIS Quarterly: Management Information Systems, 29(1), 87-111. https://doi.org/10.2307/25148669

Brewer, C. (2010). Servant Leadership: A Review of Literature. Online Journal of Workforce Education and Development, $\operatorname{IV}(2), 1-8$.

Brown, S. P., \& Leigh, T. W. (1996). A New Look at Psychological Climate and Its Relationship to Job Involvement, Effort, and Performance. Journal of Applied Psychology, 81(4), 358-368. https://doi.org/10.1093/philmat/nkj016

Chinomona, R., Mashiloane, M., \& Pooe, D. (2013). The influence of servant leadership on employee trust in a leader and commitment to the organization. Mediterranean Journal of Social Sciences, 4(14), 405-414. https://doi.org/10.5901/mjss.2013.v4n14p405

Ehrhart, M. G. (2004). Leadership and procedural justice climate as antecedents of unit-level organizational citizenship behavior. Personnel Psychology, 57(1), 61-94. https://doi.org/10.1111/j.1744-6570.2004.tb02484.x

Goh, S.-K., \& Low, B. Z.-J. (2014). The Influence of Servant Leadership towards and Organizational Commitment: The Mediating Role of Trust in Leaders. International Journal of Business and Management, 9(1). https://doi.org/10.5539/ijbm.v9n1p17

Gould-Williams, J. (2003). The importance of HR practices and workplace trust in achieving superior performance: A study of public-sector organizations. International Journal of Human Resource Management, 14(1), $28-54$. https://doi.org/10.1080/09585190210158501

Greenleaf, R. (1977). The Servant as Leader: A Journey and The Nature of Legitimate Power and Dgeatness.

Gregory Stone, A., Russell, R. F., \& Patterson, K. (2004). Transformational versus servant leadership: A difference in leader focus. Leadership \& Organization Development Journal, 25(4), 349-361. https://doi.org/10.1108/01437730410538671

Hair., J., Black, W. C., Babin, B. J., \& Anderson, R. E. (2009). Multivariate Data Analysis (Seventh Ed).

Jalagat, R. (2016). Job performance, job satisfaction, and motivation: a critical review of their relationship. Internation Journal of Advances in Management and Economics, 5(6), 36-42.

Joseph F. Hair, J., Hult, G. T. M., Ringle, C. M., \& Sarstedt, M. (2017). A Primer on Partial Least Squares Structural Equation Modeling (PLS-SEM) (second Edi). https://doi.org/10.1007/s10995-012-1023-x [doi]

Kadarusman, S., Troena, E. A., \& Ratnawati, K. (2019). The Influence Between Entrepreneurial Orientation and Organization Performance Role-Playing Organization and Competitive Advantage as a Mediation Variable. Journal Of Engineering and Applied Science, 14(14), 4703-4712.

Kheiry, B., \& Alirezapour, M. (2012). The Effect of Satisfaction, Trust and Switching Barriers Service Provider on Customer Loyalty ( Mobile Phone Users of Iran Cell Campany In Iran ). Australian Journal of Basic and Applied Sciences, 6(12), $52-60$.

Kumar, K., Bakhshi, A., \& Rani, E. (2009). Linking the Big Five personality domains to Organizational citizenship behavior. International Journal of Psychological Studies, 1(2), 73-81. https://doi.org/10.5539/ijps.v1n2p73

Kuruppuge, R. H., \& Gregar, A. (2017). Knowledge sharing and job performance: the intervening role of technological competency in knowledge-based industries. International Journal of Economics and Statistics, 5(April), 15-20.

LI, A. N., \& Tan, H. H. (2012). What happens when you trust your supervisor? Mediators of individual performance in trust relationships. Journal of Organizational Behavior, 34(3), 407-425. https://doi.org/10.1002/job.1812

Liden, R. C., Wayne, S. J., Meuser, J. D., Hu, J., Wu, J., \& Liao, C. (2015). Servant leadership: Validation of a short form of the SL-28. Leadership Quarterly, 26(2), 254-269. https://doi.org/10.1016/j.leaqua.2014.12.002

Liden, R. C., Wayne, S. J., Zhao, H., \& Henderson, D. (2008). Servant leadership: Development of a multidimensional 
measure and multi-level assessment. Leadership Quarterly, 19(2), 161-177. https://doi.org/10.1016/j.leaqua.2008.01.006

Manzoor, F., Wei, L., Nurunnabi, M., Subhan, Q. A., Shah, S. I. A., \& Fallatah, S. (2019). The impact of transformational leadership on job performance and CSR as mediator in SMEs. Sustainability, 11(436), 1-14. https://doi.org/10.3390/su11020436

Mayer, D. M., Bardes, M., \& Piccolo, R. F. (2008). Do servant-leaders help satisfy follower needs? An organizational justice perspective. European Journal of Work and Organizational Psychology, 17(2), 180-197. https://doi.org/10.1080/13594320701743558

Mayer, R. C., Davis, J. H., \& Schoorman, F. D. (1995). An Integrative Model of Organizational Trust. The Academy of Management Review, 20(3), 709-734.

Melchar, D., \& Bosco, S. (2010). Achieving High Organization Performance through Servant Leadership. Journal of Business Inquiry, 9(1), 74-88.

Nobari, E., Mohamadkhani, K., \& Davoudi, A. M. (2014). The Relationship between Servant Leadership and Organizational Citizenship Behavior of Employees at Valiasr Academic Complex, Islamic Azad University-Central Tehran Branch. International Journal of Management Business Resources, 4(4), 247-254.

Nonaka, I. (1994). A dynamic theory of organizational knowledge creation. Organization Science, 5(1), 14-37.

Podsakoff, P. M., Mackenzie, S. B., Robert H. Moorman, \& Fetter, R. (1990). Transformational Leader Behaviors And Their Effects On Followers' Trust In Leader, Satisfaction, And Organizational Citizenship Behaviors. Leadership Quarterly, $1(2), 107-142$.

Reinke, S. J. (2004). Service before self: Towards a theory of servant-leadership. Global Virtue Ethics Review, 5(3), 30-57.

Renzl, B. (2008). Trust in management and knowledge sharing: The mediating effects of fear and knowledge documentation. Omega, 36(2), 206-220. https://doi.org/10.1016/j.omega.2006.06.005

Rezaei, M., Salehi, S., Shafiei, M., \& Sabet, S. (2012). Servant Leadership and Organizational Trust the Mediating Effect of the Leader Trust and Organizational Communication. Emerging Markets Journal, 2, 70-78.

Robbins, S. P., \& Judge, T. A. (2017). Organizational Behavior, Global Edition (17th ed.). England: United Kingdom issued by the Copyright Licensing Agency Ltd.

Salanova, M., Agut, S., \& Peiró, J. M. (2005). Linking organizational resources and work engagement to employee performance and customer loyalty: The mediation of service climate. Journal of Applied Psychology, 90(6), $1217-1227$. https://doi.org/10.1037/0021-9010.90.6.1217

Schoorman, F. D., Mayer, R. C., \& Davis, J. H. (2007). An integrative model of organizational trust: Past, present, and future. Academy of Management Review, 32(2), 344-354. https://doi.org/10.5465/AMR.2007.24348410

Sendjaya, S., \& Sarros, J. C. (2002). Servant leadership: It's origin, development, and application in organizations. Journal of Leadership \& Organizational Studies, 9(2), 57-64. https://doi.org/10.1177/107179190200900205

Sharma, D., Borna, S., \& Stearns, J. M. (2009). An investigation of the effects of corporate ethical values on employee commitment and performance: Examining the moderating role of perceived fairness. Journal of Business Ethics, 89(2), 251-260. https://doi.org/10.1007/s10551-008-9997-4

Sial, A., Zulfiqar, S., Kousar, S. W. A., \& Habib, S. (2014). Impact of servant leadership on knowledge sharing intentions. European Journal of Business and Innovation Resarch, 2(1), 1-11.

Singh, K., \& Desa, Z. M. (2018). Organizational Trust And Job Performance: A Study Of Land And Survey Department. International Journal of Academic Research in Business and Social Sciences, 8(11), 1954-1961. https://doi.org/10.6007/ijarbss/v8-i11/5559

Srivastava, A., Bartol, K. M., \& Locke, E. A. (2006). Empowering leadership in management teams: Effects on knowledge sharing, efficacy, and performance. Academy of Management Journal, 49(6), 1239-1251.

Tenenhaus, M., Vinzi, V. E., Chatelin, Y. M., \& Lauro, C. (2005). PLS path modeling. Computational Statistics and Data Analysis, 48(1), 159-205. https://doi.org/10.1016/j.csda.2004.03.005

Treadway, D. C., Hochwarter, W. A., Ferris, G. R., Kacmar, C. J., Douglas, C., Ammeter, A. P., \& Buckley, M. R. (2004). Leader political skill and employee reactions. Leadership Quarterly, 15(4), 493-513. https://doi.org/10.1016/j.leaqua.2004.05.004

Wang, S., \& Noe, R. A. (2010). Knowledge sharing: A review and directions for future research. Human Resource Management Review, 20(2), 115-131. https://doi.org/10.1016/j.hrmr.2009.10.001

Yang, J. Te. (2007). The impact of knowledge sharing on organizational learning and effectiveness. Journal of Knowledge Management, 11(2), 83-90. https://doi.org/10.1108/13673270710738933

Zargar, P., Sousan, A., \& Farmanesh, P. (2019). Does trust in leader mediate the servant leadership style - job satisfaction relationship? Management Science Letters, (July), 2253-2268. https://doi.org/10.5267/j.msl.2019.7.028

Zimmermann, A., \& Ravishankar, M. N. (2014). Knowledge transfer in IT offshoring relationships: The roles of social capital, efficacy and outcome expectations. Information Systems Journal, 24(2), 167-202. https://doi.org/10.1111/isj.12027 
(C) 2021 by the authors; licensee Growing Science, Canada. This is an open access article distributed under the terms and conditions of the Creative Commons Attribution (CC-BY) license (http://creativecommons.org/licenses/by/4.0/). 